\title{
Revisiting Gavello's procedure for single-stage reconstruction of the earlobe: The vascular basis, technique and clinical uses
}

\author{
Debarati Chattopadhyay MS, Souradip Gupta MBBS, Marang Buru Murmu MS, \\ Goutam Guha MS MCh, Sandipan Gupta MS MCh
}

\begin{abstract}
D Chattopadhyay, S Gupta, MB Murmu, G Guha, S Gupta. Revisiting Gavello's procedure for single-stage reconstruction of the earlobe: The vascular basis, technique and clinical uses. Can J Plast Surg 2012;20(2):22-24.
\end{abstract}

BACKGROUND: Deformities or loss of the earlobe may be congenital, or acquired due to trauma, bites, burns or tumour excision. A variety of single-stage and two-stage procedures have been described for earlobe reconstruction, of which Gavello's procedure was one of the earliest.

OBJECTIVE: To revisit Gavello's procedure with reference to the vascular supply of the flap, and discuss the relevance of the technique in current practice.

METHODS: The authors discuss the vascular basis of Gavello's flap, and describe the clinical application of the single-stage Gavello's procedure in diverse clinical situations, including congenital absence of earlobe, postburn earlobe deformity and traumatic amputation of the earlobe.

RESULTS: Excellent cosmetic results have been achieved in all different clinical situations in the authors' experience, with preservation of earlobe shape and volume, good colour match and a well-concealed scar in the donor area.

DISCUSSION: Gavello's procedure is a simple, one-stage procedure that relies entirely on local tissue for earlobe reconstruction; the flap has a predictable vascular supply, skin grafting is not required and the procedure can be used for large defects. An intact donor area over the postauricular mastoid region is a prerequisite.

CONCLUSION: The simple, century-old Gavello's procedure is still of great value for reconstruction of earlobe defects of diverse etiology.

Key Words: Earlobe deformity; Earlobe reconstruction; Gavello's flap; Gavello's procedure

\section{Examiner l'intervention de Gavello en cas de reconstruction du lobe de l'oreille en une étape : la base vasculaire, la technique et les utilisations cliniques}

HISTORIQUE : Les anomalies ou la perte du lobe de l'oreille peuvent être d'origine congénitale ou être acquises en raison d'un traumatisme, de morsures, de brûlures ou d'excision d'une tumeur. Diverses interventions en une ou deux étapes ont été décrites pour reconstruire le lobe de l'oreille. L'intervention de Gavello est l'une des plus anciennes.

OBJECTIF : Examiner l'intervention de Gavello compte tenu de la capacité vasculaire du lambeau et exposer la pertinence de cette technique dans la pratique actuelle.

MÉTHODOLOGIE : Les auteurs abordent la base vasculaire du lambeau de Gavello et décrivent l'application clinique de l'intervention de Gavello en une étape dans diverses situations, y compris l'absence congénitale de lobe d'oreille, une malformation du lobe de l'oreille après une brûlure et une amputation traumatique du lobe de l'oreille.

RÉSULTATS : Les auteurs ont remarqué d'excellents résultats esthétiques dans toutes sortes de situations cliniques, qui permettent de préserver la forme et le volume du lobe de l'oreille ainsi que d'obtenir une bonne correspondance de la couleur et une cicatrice bien cachée au foyer du donneur.

EXPOSÉ : L'intervention de Gavello est une intervention simple en une étape qui fait entièrement appel à des tissus locaux pour reconstruire le lobe de l'oreille. Le lambeau a une capacité vasculaire prévisible, la greffe de peau est inutile et l'intervention peut être utilisée pour des anomalies importantes. La région de la mastoïde postauriculaire du donneur doit être intacte.

CONCLUSION : L'intervention de Gavello, qui est simple et existe depuis un siècle, est toujours très précieuse pour la reconstruction d'anomalies du lobe de l'oreille d'étiologies variées.

supplies the cranial surface of the auricle via its auricular branch, and the occipital belly of occipitofrontalis and the scalp behind and above the auricle via its occipital branch (3). Our observation of digital subtraction angiography (DSA) images of different individuals undergoing DSA for unrelated causes revealed that the occipital branch of the posterior auricular artery that runs horizontally behind the ear is a constant vessel in the area where Gavello's flap is raised (Figure 1).

Description of the procedure: Figures $2 \mathrm{~A}$ and $2 \mathrm{~B}$

A straight line $(A-B)$ is drawn on the postauricular mastoid skin, along the cut margin of the earlobe. This line is further extended posteriorly to a point $C$, so that $A B=B C$. A point $D$ is marked approximately $1 \mathrm{~cm}$ vertically below the point $A$. From point $D$, a double-curved line (D-E-C) is drawn, joining points D and C. The bilobed flap thus formed is raised by subcutaneous dissection with caution to avoid injury to the posterior auricular artery, which runs at the base (A-D) of the flap. The cut margin of the earlobe is paired and freshened. The bilobed flap is folded on itself along B-E. AB and BC are sutured with the anterior and posterior paired margins of the 


\section{DISCUSSION}

The earlobe is a small but aesthetically crucial structure. The challenge in earlobe reconstruction surgery is to obtain a natural-appearing structure with a durable outcome. The technique should be simple, preferably performed in one stage, suitable for earlobe defects of all sizes and volume, and yield acceptable cosmetic results.

A variety of single-stage and two-stage reconstructive techniques have been described for earlobe reconstruction. These techniques mainly use local skin flaps from the preauricular, infra-auricular, retroauricular, retromandibular areas or the auricular surface, depending on the flap design: doubled-over single or bilobed flaps $(1,2,4-10)$, superimposition of two opposing or paired flaps (11-14) or double-crossed flaps (15) may be used; some techniques require a skin graft in addition to the flap $(6,16,17)$. Some of the procedures involve the incorporation of a cartilage graft into the reconstructed earlobe to maintain shape (18-20)

The advantages of the Gavello technique are as follows: it is a simple, one-stage procedure; it is suitable for both immediate and delayed reconstruction; it relies entirely on local tissue for reconstruction; the flap has a predictable vascular supply; skin grafting is not required; it yields excellent cosmetic results with preservation of earlobe shape and volume; excellent colour match; the donor site scar is well-concealed; and the procedure can be used for large defects or even total loss of earlobe, as shown in case 3 of the present series. The limitation of the procedure is the requirement of an intact donor area over the postauricular mastoid region.

\section{CONCLUSION}

In the present article, we revisited Gavello's procedure of earlobe reconstruction with an attempt to understand the vascular basis of the

\section{REFERENCES}

1. Gavello P: Quoted by Nélaton C, Ombrédanne L. Les Autoplasties. Paris: G. Steinheil, 1907

2. Converse JM, Brent B. Acquired deformities of the auricle. In: Converse JM, ed. Reconstructive Plastic Surgery, 2nd edn. Philadelphia: Saunders, 1977:1724-73.

3. Standring S, ed. Gray's Anatomy: The Anatomical Basis of Clinical Practice, 40th edn. Philadelphia: Churchill Livingstone Elsevier, 2008:491

4. Alanis SZ. A new method for earlobe reconstruction. Plast Reconstr Surg 1970;45;254-7.

5. Preaux J. A simple procedure for reconstruction of the lower part of the auricle. Ann Chir Plast 1971;16;60-2 [In French].

6. Brent B. Earlobe construction with an auriculomastoid flap. Plast Reconstr Surg 1976;57;389-91.

7. D'Hooghe PJ. Earlobe reconstruction with a bilobed caudally-based flap. Plast Reconstr Surg 1977;59;764.

8. Okada E, Maruyama Y. A simple method for earlobe reconstruction. Plast Reconstr Surg 1998;101:162-6.

9. Singh A, Singh G. Earlobe reconstruction using a Limberg flap in six ears. Br J Plast Surg 2003;56;33-6.

10. Rodríguez FF, Cecilia JN, Torrejón LR. Earlobe reconstruction with a modified bilobed flap. <www.PRSJournal.com> (Accessed December 09, 2011) DOI:10.1097/ PRS.0b013e3181dab329.
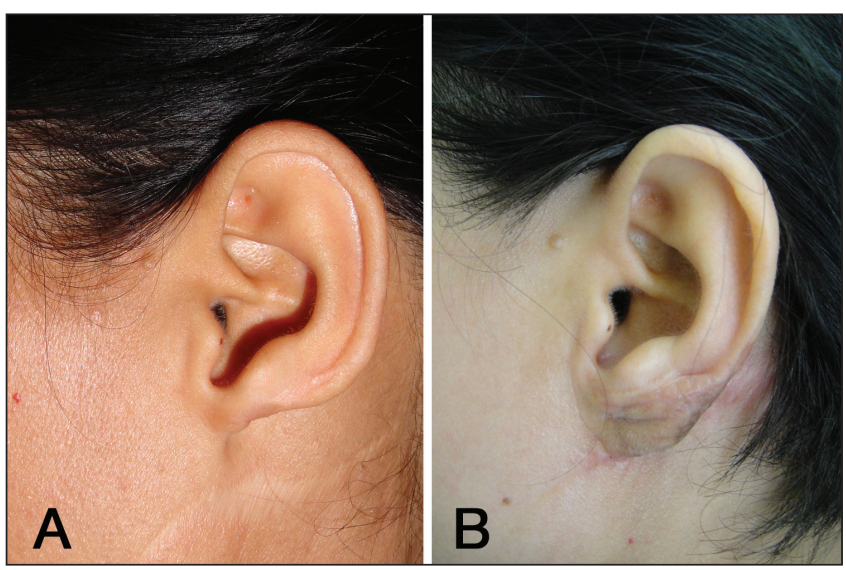

Figure 5) Results of Gavello's procedure in traumatic amputation of earlobe. A Preoperative photograph. B Postoperative outcome

procedure, and demonstrated the excellent results that can be achieved with this century-old technique for earlobe defects of diverse etiology. Thus, it can be concluded that such 'old', simple flaps are still of great value.

DISCLOSURES: The authors have no financial disclosures or conflicts of interest to declare.

11. Converse JM. Traumatic deformities of the auricle. In: Kazanjian VH, Converse JM, eds. Surgical Treatment of Facial Injuries, 3rd edn. Baltimore: Williams \& Wilkins, 1974.

12. Davis JE. Repair of traumatic defects of the auricle. In: Tanzer RC, Edgerton MT, eds. Symposium on Reconstruction of the Auricle. St Louis: Mosby, 1974:247.

13. Mohan M, Appukuttan PK, Srinivasan A. Earlobe reconstruction with a preauricular flap. Plast Reconstr Surg 1978;62;267-70.

14. Alconchel MD, Rodrigo J, Cimorra A. A combined flap technique for earlobe reconstruction in one stage. Br J Plast Surg 1996;49;242-4.

15. Sleilati F. Immediate earlobe reconstruction with double-crossed skin flaps. J Plast Reconstruct Aesthet Surg 2006;59;1003-5.

16. Converse JM. Reconstruction of the auricle: part II. Plast Reconstr Surg 1958;22;230-49.

17. Subba Rao YV, Venkateswara Rao P. A quick technique for ear lobe reconstruction. Plast Reconstr Surg 1968;41:13-6.

18. Ohsumi N. Earlobe reconstruction with a reversed flow chondrocutaneous postauricular flap and a local flap. Plast Reconstr Surg 1994;94;364-8.

19. Yotsuyanagi T. Earlobe reconstruction using a chondrocutaneous flap. Plast Reconstr Surg 1994;94:1073-8.

20. Yotsuyanagi T, Yamashita K, Sawada Y. Reconstruction of congenital and acquired earlobe deformity. Clin Plast Surg 2002;29;249-55. 